doctrine of "Apostolic Succession," with the difference that on this principle the Church ensures the undoubted merit and high position of the members upon whom bonour is conferred. In the case of the companies, however, there is no such guarantee; the most popular member socially and the man who knows best how to dine well is generally pushed to the front. That the Apothecaries' Company happens to be represented on the General Medical Council by so able an adrocate of its peculiar claims as Mr. Brudenell Carter is quite an accident, and the power behind him is practically represented by the votes of probably five electors, more or less, and of the value of their judgment and capacity for selection we know but little. Dr. Rentoul will be able to enlighten the Council and the profession upon this matter, for Mr. Carter will find in his new colleague an expert in knowledge of all the little nays of the "close corporations." Mr. Carter assures us that direct representation is now removed from the range of practical politics. I would remind this gentleman that it is but a short time since this was aaid of the Parliamentary franchise, and he may be perfectly satisfied that universal direct representation of the profession upon the General Medical Council will be adopted in the near future, for the Statute of Limitation has no place in such matters - I am, Sirs, yours faithfully,

old Trafford, Dec. 22nd, 1895. J JAMES BRAsSGY BRIERLEY.

\section{THE EIGHTH INTERNATIONAL CONGRESS OF HYGIENE AND DENOGRAPHY : PUBLICATION OF TRANSACTIONS.}

To the Editors of THE LANCET.

SIRS,-I beg to inform you that the Transactions of the Eighth Interuational Congress of Hygiene and Demography held at Budapest in September, 1894, are now ready for publication, and the remaining seven volumes will be sent out early in January, 1897. As many members might have since changed their residence, I would feel greatly obliged if you would kindly publish this note in your valuable periodical in order that members might be able to send in their addresses in time to the Editor (Dr. Sgmd. de Gerloczy, St. Rochus Hospital, Badapest). An extra copy of the Transactions will be also sent to you for your own use.

1 remain, Sirs, yours obediently,

Budapest, December, $1896 . \quad$ Dr. GerLóczY (The Editor).

\section{THE REPORT OF THE ROYAL COMMISSION ON VACCINATION. \\ To the Editors of THE LANCET.}

Sins,-A weak result of a weak-kneed Commission, or as you better, certainly more Parliamentarily, put it, "Once more we have to point out that the omission to recommend re-vaccination as an administrative duty constitutes the one great flaw in the very valuable deliverance of the Commissioners." It would be well, if vaccination is to be saved to us in its whole utility, for some sound-minded member of the profession, with good time on his hands and living near the British Museum, to work through, from the time of Jenner's stupendous discovery, a dozen newspapers-say six London and six provincial ones-and to give the public in cheap pamphlet form quotations from each newspaper for each year, especially those with reference to the delight of the public in the gradual diminution of the effects of small poxviz., mortality, loss of noses and eyes, and general pitting of the faces-also noting the reports from foreign countries which show equal delight in the use of vaccination and, as the years went on, the value of re-vaccination. Injury from vaccination-such as erysipelas and syphilis-I take it, would be aroided if no vaccination was made exceps from calf vaccine supplied by Gopernment or their recognised agents, or pussibly, by public vaccinators-in this latter case with lymph only once removed from calf. I say, "possibly," because I have reason to believe from my small experience that vaccination with calf lymph sometimes fails and that raccination only succeeds when humanised calf lymph is used.

I would say let Parliament make vaccination and revaccination compulsory, and each for the first time to be made with calf raccine; on failing to repeat with calf vaccine; but on second failures that once humanised calf lymph should be used. I am, Sirs, yours faithfully,

Canterbury, Dec. 25th, 1895. PUgin Thorntox.

\section{"THE NEW SYDENHAM SOCIETY'S MEDICAL LEXICON."}

To the Ed tors of THE LANCET.

Sins,-Mr. Kestever's letter on the slow rate of publication of the New Sydenham Society's Medical Lexicon deserves some attention from the council of the sociaty. I attended the last annual meeting of the socitty and urged that an attempt should be made to conclude the Lexicon. before the close of the century. There was not a large meeting of members, only about half a dozen being present but this, I am informed, is the usual number who attend oa such occasions. The society has a president, 16 vicepresidents, 32 members of council, 1 treasurer, 3 auditore, and 1 honorary secretary, but none of these officials were present and no one could explain the slow rate of progress in the publication of the Lexicon. The chairman, however, promised to forward a strong representation of the wishes of the meeting that some effort should be made to bring the publication to a conclusion.

I am, Sirs, yours faitbfully,

Carlisle, Dec. 28th, $1896 . \quad$ HenRy BARNes, M.D. Edin.

\section{"ALLEGED ARSENICAL POISONING." To the Editors of THE LANCET.}

SIR, -Dr. Murrell has written his letter ${ }^{1}$ uncer a misapprehension. I stated that the fabric to which he refers contained approximately $50^{2}$ th of a grain of arsenic per square yard. In this I was supported by Mr. W. Thomson, who found the same proportion. This is only one part in 1300,000 of the fabric. Hence Dr. Murrell's criticisms on what he supposes I said fall to the ground. Every point to which he refers was fally before the court--the delicacy of the tests for arsenic and for determining its amount when admixed with organic matter, the proper doses when taken by the mouth, and the influence of inlualation upon the dose. I am, Sirs, yours faithtully,

Guy's Hospital, Dec. 29th, $1896 . \quad$ Thomas STtuvenson.

\section{"THE TRAINING OF NURSES IN RELATION} TU REGISTRATION."

\section{To the Editors of THE LANCET.}

SIRS,-If you had waited to hear the other side of the story your correspondent has told you you would have found that the feeling of discontent to which you refer as arising among the members of the Royal British Nurses Association is limited to a small minority. The facts are these. A proposal was laid before the council of the association in July last to admit properly trained and qualified mental nurses into the association. This matter was referred to a committee of the council who reported strongly in favour of the proposal, and the report was unanimously adopt $\epsilon$. Now before the details have even been discussed by the executive committee a letter has been sent out signed by sophia Wingfield, protesting against the admission of "untrained asylum attendants as members of the association," and stating that once the "asylum attendants are admitted as registered members of the corporation of trained nurses the public will have no means of protecting themselves against untrained persons." This is not the case. The proposal is that none but mental nurses of not less than three years' training in a hospital or asylum for the insane with not less than forty beds shall be admitted to registration, and it will be necessary for each nuree to possess the certificate of the Medico-Psychological Association for proficiency in nursing. This certificate can only be procured after a rigid curriculum of instruction and practical tuition and training in the nursing of the sick and insane now carried on in every hospital and asylum in the kingdom under the direction and practical instruction by the medical staff and attendance upcn conrses of lectures and demonstrations followed by strirgent 